\title{
Evaluation of the Efficiency Energy of Wood Stove from Irati Brazilian City
}

\author{
Pâmela Caroline Lau ${ }^{1}$, Gilmara de Oliveira Machado ${ }^{1}$, Luiz Augusto Horta Nogueira ${ }^{2}$, \\ André Luis Chris toforo ${ }^{3, *}$ Decio Gonçalves ${ }^{4}$, Francis co A. Rocco Lahr ${ }^{4}$ \\ ${ }^{1}$ Department of Forestry, Midwest State University (UNICENTRO), Irati, 3421-3000., Brazil \\ ${ }^{2}$ Natural Resources Institute, Federal University of Itajubá (UNIFEI), Itajubá, 37500-903, Brazil \\ ${ }^{3}$ Department of Mechanical En gin eering, Federal Univ ersity of São João del-Rei, São João del-Rei, 36307-352, Brazil \\ ${ }^{4}$ Department of Structural Engineering, En gin eering School of São Carlos (EESC/USP), São Carlos, 13566-590, Brazil
}

\begin{abstract}
This study aimed to evaluate the energy efficiency, thermal power and a mount of volatiles released $\left(\mathrm{CO}_{2}, \mathrm{CO}\right.$ and $\mathrm{SO}_{2}$ ) by three models of wood-metallic cookstoves into single-family residences in the city of Irati / PR, Brazil. All cookstoves had a low average energy efficiency fro $\mathrm{m} 2.9 \% \pm 0.3$ (stove 1 ), $2.6 \% \pm 0.5$ (stove 2 ) to $4.6 \% \pm 0.2$ (stove 3 ). The thermal power was $159.3 \mathrm{~W} \pm 14.2$ (stove 1 ), $142.7 \mathrm{~W} \pm 39.2$ (stove 2) and $176.5 \mathrm{~W} \pm 21.7$ (stove 3 ). It was observed a high pollutant levels of volatile compounds such as $\mathrm{CO} 34,9 \mathrm{Nm}^{3} / \mathrm{kg} \pm 3,1 ; 35,2 \mathrm{Nm}^{3} / \mathrm{kg} \pm 8,6$ and $24,5 \mathrm{Nm}^{3} / \mathrm{kg} \pm 2,1 ; \mathrm{CO}_{2} 314,4$ $\mathrm{Nm}^{3} / \mathrm{kg} \pm 28,3 ; 316,5 \mathrm{Nm}^{3} / \mathrm{kg} \pm 77,0$ and $220,9 \mathrm{Nm}^{3} / \mathrm{kg} \pm 19,0$, lastly $\mathrm{SO}_{2} 0,027 \mathrm{Nm}^{3} / \mathrm{kg} \pm 0,0 ; 0,027 \mathrm{Nm}^{3} / \mathrm{kg} \pm 0,0$ and 0,019 $\mathrm{Nm}^{3} / \mathrm{kg} \pm 0,0$, respectively from first to third stove. The results of the analysis of variance showed that the stove 3 showed to be the most efficient among the models investigated. In general, the obtained data indicate a low energy conversion and a potential health risk to the user due the release of toxic gases, such as carbon monoxide, present in the smoke inside the house's kitchen.
\end{abstract}

Keywords Wood stove, Eucalyptus grandis, Energetic effic iency

\section{Introduction}

Circa three billion people worldwide depend on biomass plant for cooking food and heating. Approximately 50-60\% use wood, often indoors with poor ventilation, subjecting themselves to daily exposure to high concentrations of smoke fro $m$ the stove inside the kitchen, making a big impact on health especially of wo men and their young children. The smoke from burning wood contains hundreds of toxic substances, including carbon monoxide and dioxins and furans which are the most toxic compounds known to science[1-3].

Obtaining energy from biomass for cooking food is traditionally performed by direct combustion (burning) of wood or on a smaller scale charcoal in thermal equipment called "wood stoves". However, the efficiency of these ranges, which can vary from $2 \%$ to $36 \%$, depends upon the conversion of fuel into heat energy, technology and type of construction[4-5]. Table 1 shows the global efficiency data recorded in different types of ovens (Figure 1) for cooking food in commercial use.

* Corresponding author:

alchristo foro@y ahoo.com.br (André Luis Christoforo)

Published online at http://journal.sapub.org/ijaf

Copyright (C) 2013 Scientific \& Academic Publishing. All Rights Reserved
Table 1. Efficiency data of different models of charcoal or wood stoves

\begin{tabular}{lc}
\hline \multicolumn{1}{c}{ Type of stove } & Efficiency (\%) \\
\hline Three stones (A) & $7-15$ \\
"Heavy" with fireplace (B) & $15-23$ \\
No chimney for a pot (D) & $30-35$ \\
No chimney pot for two (E) & $18-22$ \\
Compact sawdust (H) & $15 / 32-36$ \\
Gas stove & 57 \\
Electric stove & 50 \\
\hline
\end{tabular}

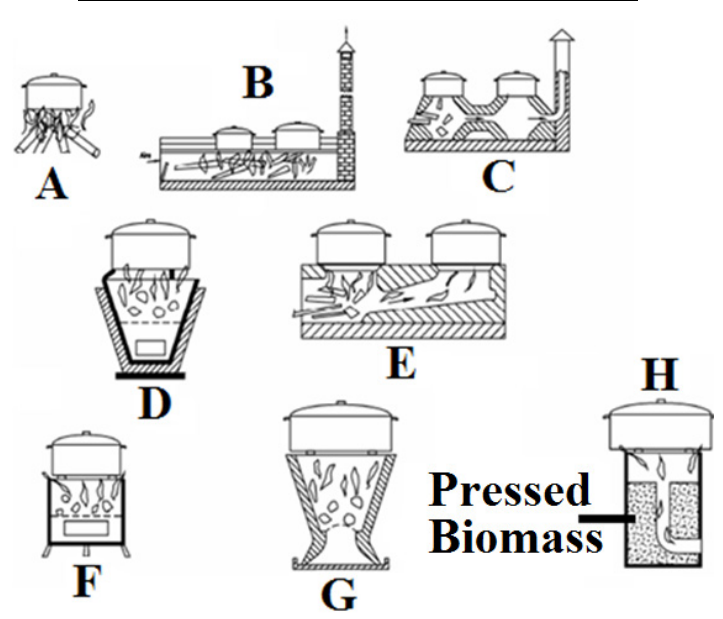

Figure 1. Different models of stove: Source: Regueira[5] 
From Table 1 and Figure 1, A illustrates the three-stone stove, the stove B "heavy" with chimney, C "light" with chimney, D no chimney for a pot, and no chimney for two pots, metallic F for coal vegetable charcoal, ceramic, G and H compact sawdust.

In the Brazilian scenario, the wood has a significant stake of $7.2 \%$, while in the residential wood is used mainly for cooking food on a smaller scale, especially in temperate regions in home heating. In the context of thermal energy consumption by households, the wood has an interest equivalent to that of liquefied petroleum gas (Figure 2), which according to Brito[6], has been the natural replacement in most urban households and for which, the unlike wood, official policy incentives have always been present.

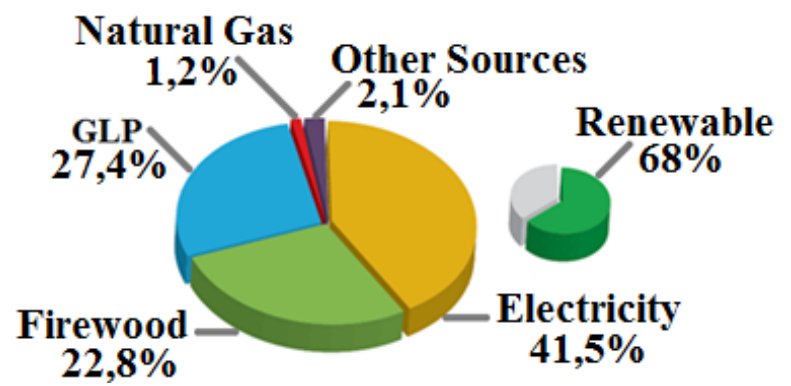

Figure 2. Energy consumption by Brazilian families

The conventional wood stoves have low energy efficiency, around $7 \%$ in the central southern Brazilian. The inefficiency is due to the burning flame rapidly diffuse. The use of thermal energy released is not complete in equipment with inadequate insulation of the combustion chamber and insufficient air circulation. These stoves produce emission of volatiles and particulates, causing serious pollution when located inside the residences. It is quite common that users have respiratory failure, eye diseases, chronic bronchitis and skin darken ing[5-3].

Borges[7] states that the inefficiency of stoves enhances the emission of to xic gases such as carbon mono xide, besides promotes a large wood consumption. Additionally, there is a high occurrence of deforestation, since the majority of the wood used does not come from planted forests rather than manual collection in native forests.

\section{Material and Methods}

In this study was performed a survey of user profiles, characteristics of thermal equip ment by visual inspection and frequency of use (Table 1). The method used was the open interviews with both the user as to the manufacturer of the product. The three metal stoves were evaluated (Figure 3), with the primary fuel burning, have two mouths, with chimney and located inside the kitchen. Despite the presence of chimney, it was observed the occurrence of pollution from large-scale production of smoke, but without release of soot within the kitchen.

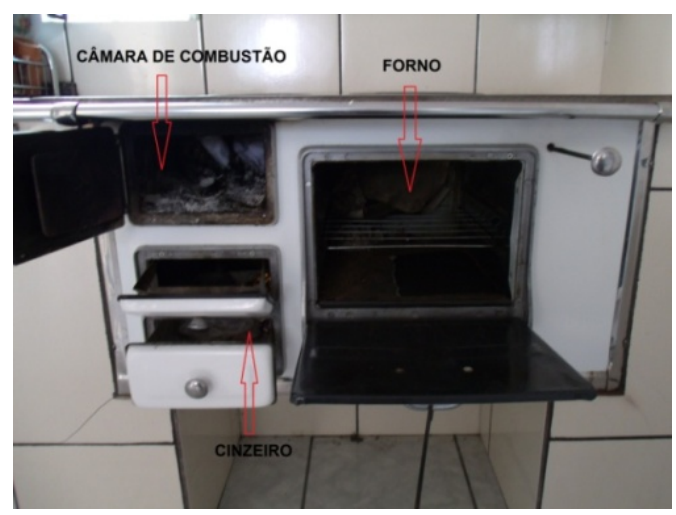

Stove 1

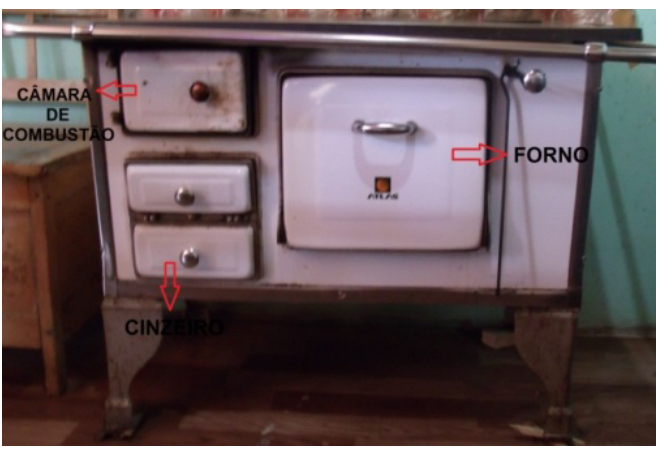

Stove 2

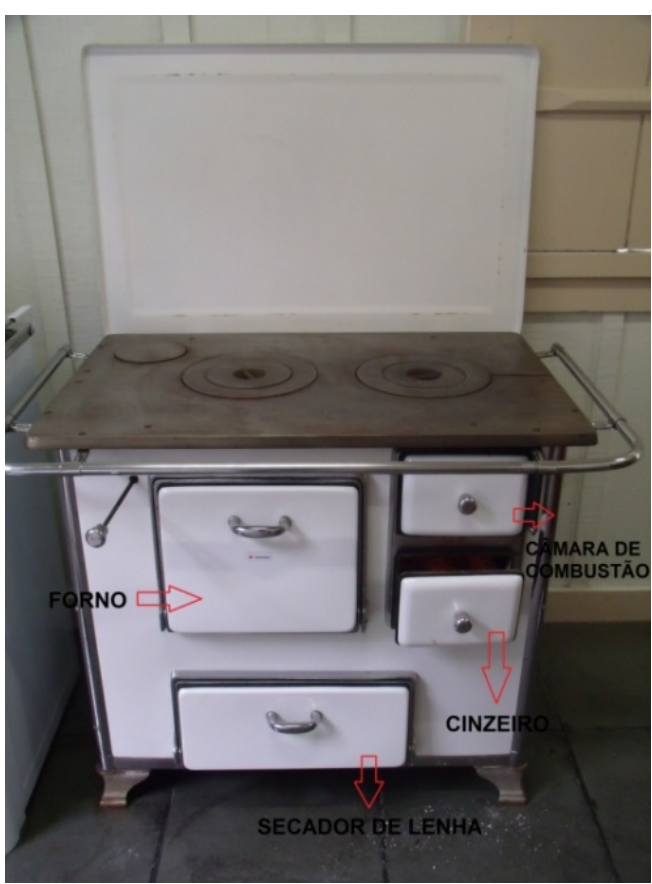

Stove 3

Figure 3. Stoves used in this research

Only the stove 3 presents thermal insulation of the combustion chamber with clay bricks laid by a mixture of cement and coarse sand in the lower compartment for storage and drying of the wood. Additional information can be found in Table 2, where there is a low incidence of respiratory diseases and variable use frequency of the families. 
Table 2. Specifications stove and frequency of use

\begin{tabular}{lc}
\hline \multicolumn{1}{c}{ Data } & Stove 1 \\
\hline Type of use & Lunch \\
Frequency of use & 2 days/week \\
Pollution generated & Smoke \\
Use of the stove & Frequent \\
Combustible & Native Forest \\
Family members & Five \\
Respiratory diseases & Bronchitis \\
\hline \multicolumn{1}{c}{ Data } & Stove2 \\
\hline Type of use & Dinner \\
Frequency of use & All days \\
Pollution generated & Smoke \\
Use of the stove & Meal of the day \\
Combustible & Exotic Forest \\
Family members & Three \\
Respiratory diseases & Nothing in \\
\hline \multicolumn{1}{c}{ Data } & Stove 3 \\
\hline Type of use & Lunch \\
Frequency of use & Weekend \\
Pollution generated & Smoke \\
Use of the stove & During the week \\
Combustible & Exotic Forest \\
Family members & Two \\
Respiratory diseases & Rhinitis \\
\hline
\end{tabular}

For the determination of moisture content of wood, dry basis, it was used the method of oven drying, which consisted in placing three small logs, representative of the sample in the oven at $105^{\circ} \mathrm{C}$, with successive weighings until constant mass was obtained. $m_{i}$ is the initial mass of the sample and $\mathrm{m}_{\mathrm{s}}$ dry weight, mo isture content $(\mathrm{U})$ is given by Equation 1[8]:

$$
\mathrm{U}=\frac{\mathrm{m}_{\mathrm{i}}-\mathrm{m}_{\mathrm{s}}}{\mathrm{m}_{\mathrm{s}}} \cdot 100(\%)
$$

For the determination of the calorific value of wood was initially performed the chemical analysis of the sample ground and then sieved, using the fraction retained on the sieves 40-60 mesh, in accordance with ASTM Standard E711-87[9]. Instant Analys is consists in determining the volatile content, ash and fixed carbon. $\mathrm{m}_{\mathrm{i}}$ is the initial dry sawdust and dry mass after heat treatment $m_{f}$, the volatiles content (TV) was determined as the weight loss at $600^{\circ} \mathrm{C}$ for 10 minutes in a muffle furnace and by Equation 2 .

$$
\mathrm{TV}=\frac{\mathrm{m}_{\mathrm{i}}-\mathrm{m}_{\mathrm{f}}}{\mathrm{m}_{\mathrm{f}}} \cdot 100(\%)
$$

For the determination of the ash content, the samples were placed in a porcelain crucible in a muffle furnace at a temperature of $750^{\circ} \mathrm{C}$ for 6 hours to complete the thermal degradation of organics. The calcined samples remained in a desiccator for cooling. The ash content (CZ) was calculated by dividing the mass of the sample after pyrolysis $\left(\mathrm{m}_{\mathrm{c}}\right)$ and initial sample dry mass $\left(\mathrm{m}_{\mathrm{i}}\right)$ by using Equation 3 .

$$
\mathrm{CZ}=\frac{\mathrm{m}_{\mathrm{c}}}{\mathrm{m}_{\mathrm{i}}} \cdot 100(\%)
$$

The determination of the percentage of fixed carbon (FC) was taken as the difference between volatile and ash content of $100 \%$. Thus, the fuel can be considered as being made in terms of chemical analys is, three fractions: fixed carbon, ash and volatiles. The test was conducted with 4 replicates. The Eucalyptus grandis showed $83.8 \pm 0.43 \%$ of volatiles, $0.31 \% \pm 0.00$ ash and $15.89 \pm 2.71 \%$ fixed carbon.

The calorific value (GCV) was determined using data from the Immediate Analysis by means of Equation 4, as proposed by Parikh et al.[10].

$$
\begin{gathered}
\mathrm{PCS}=0.3536 \cdot \mathrm{CF}+0.1559 \cdot \mathrm{TV}+0.0078 \cdot \mathrm{CZ} \\
(\mathrm{kcal} / \mathrm{kg})
\end{gathered}
$$

With the results obtained from PCS was determined value lower calorific (PCI) of firewood through Equation 5, considering the percentage of hydrogen $(\mathrm{H})$ of wood less than $6 \%[8]$ :

$$
\text { PCI }=\text { PCS }-600 \cdot\left(\frac{9 \mathrm{H}}{100}\right)(\mathrm{kcal} / \mathrm{kg})
$$

Having the value of mo isture content of wood (U) and lower heating value (LHV), the net calorific value (PCU) was calculated by Equation 6[8].

$$
\text { PCU }=\text { PCI } \cdot(1-\mathrm{U})-600 \cdot \mathrm{U}(\mathrm{kcal} / \mathrm{kg})
$$

The efficiency of a wood stove is the dimensionless ratio between the useful energy effect and power consumption of the fuel. The efficiency was calculated based on the assessment of the amount of heat absorbed by the water in a metal pan (Qútil) and the amount of heat supplied by the fuel (Qlenha) [4].

There we re performed five consecutive repetitions on each stove. Each test had duration of 20 minutes and consisted in weighing a certain amount of fuel before and after heating 2 $\mathrm{kg}$ of water, without the occurrence of boiling in an aluminum pan with lid 3 liters of capacity. The lid was attached to a central shaft with propeller in its bottom end, allowing the water to mechanical agitation to homogenize the temperature. In course of time each test, every 5 minutes, the temperature measurements made with the aid of a thermo meter. Initially the stove was lit to make your heating. After preheating the stove, began the first test where the pot remained capped all the time, except at the measurement temperature. The pot was only placed on the stove when the timber started its burning. Since $\mathrm{m}_{\mathrm{H} 2 \mathrm{O}}$ mass of water to be heated $(\mathrm{kg}) \mathrm{C}_{\mathrm{H} 2 \mathrm{O}}$ the specific heat of water $\left(\mathrm{kcal} / \mathrm{kg}{ }^{\circ} \mathrm{C}\right)$ and $\Delta \mathrm{T}_{\mathrm{H} 2 \mathrm{O}}$ the temperature difference between the beginning and end of the test (C), useful heat absorbed by the water in the pan $\left(Q_{\text {útil }}\right)$ was calculated with possession of Equation 7.

$$
\mathrm{Q}_{\text {útil }}=\mathrm{m}_{\mathrm{H} 2 \mathrm{O}} \cdot \mathrm{C}_{\mathrm{H} 2 \mathrm{O}} \cdot \Delta \mathrm{T}_{\mathrm{H} 2 \mathrm{O}} \text { (kcal) }
$$

After 20 minutes of each test, the fire was put out to dry, and all the wood waste was removed to be weighed. To achieve precision weighing, burning the residues were removed from the oven and stored in closed containers of aluminum and then placed in a closed Styrofoam box with five and cooled gel packs coolant. Subsequently, the combustion residues were taken to the Laboratory of 
Technology and Utilization of Forest Products, State University Midwestern (UNICENTRO), Irati campus, to be weighed in a semi-analytical.

Sendo a massa de lenha consumida no aquecimento da água $\left(\mathrm{m}_{\mathrm{q}}\right)$, diferença entre a massa de lenha inicial e a massa do resíduo da combustão e $\mathrm{PCU}_{1}$ o poder calorífico líquido da lenha, o calor total fornecido pela queima da lenha ( $\left.Q_{\text {lenha }}\right)$ é calculado como uso a Equação 8.

The mass of consumed firewood in heating water $\left(\mathrm{m}_{\mathrm{q}}\right)$, the difference between the initial mass and the mass of wood waste combustion and $\mathrm{PCU}_{1}$ the net calorific value of the fuel, the total heat supplied by burning firewood $\left(\mathrm{Q}_{\text {lenha }}\right)$ is calculated using Equation 8.

$$
\mathrm{Q}_{\text {lenha }}=\mathrm{PCU}_{1} \cdot \mathrm{m}_{\mathrm{q}}(\mathrm{kcal})
$$

The efficiency of the stove (Ef) was obtained through the result of the ratio of the heat absorbed by the water (useful heat) and the energy released by firewood (Equation 9).

$$
\mathrm{Ef}=100 \cdot\left(\frac{\mathrm{Q}_{\text {útil }}}{\mathrm{Q}_{\text {lenha }}}\right)(\mathrm{kcal})
$$

A potência calorífica do fogão está diretamente relacionada com o calor produzido pela lenha, através do seu poder calorífico, o tempo de queima da lenha $(\Delta \mathrm{T})$ e a eficiência. A potência do fogão (Pf) é dada pela Equação 10, sendo $\mathrm{m}_{\mathrm{q}}$ a massa de lenha queimada.

The heating power of the stove is directly related to the heat produced by burning through its calorific value, time of burning firewood $(\Delta \mathrm{T})$ and efficiency. The power of the stove $(\mathrm{Pf})$ is given by Equation 10 , where $\mathrm{m}_{\mathrm{q}}$ the mas s of fuel burned.

$$
\mathrm{Pf}=\frac{\mathrm{m}_{\mathrm{q}} \cdot \mathrm{PCU}_{1} \cdot \mathrm{Ef}}{\Delta \mathrm{T}}(\mathrm{kW})
$$

The majority of the methods used to evaluate the wood stoves are based only on the thermal performance of the device, ignoring the emis sions of pollutants. However, wood stoves release large amounts of volatile and toxic gases, the user submitting the exhibits extremely harmful to health. Thus, it was used to estimate the a mount of $\mathrm{CO}_{2}, \mathrm{SO}_{2}$ and $\mathrm{CO}$ released by metal stoves.

According to literature data, the average amount of $\mathrm{CO}$ released in incomplete burning of wood, wood stoves metal is ten percent content of the gases from the combustion of carbon[11]. By having the Elemental Analysis values, it is possible to present the balanced equation combustion of firewood, Equation 10, and thus determine the concentrations of $\mathrm{CO}, \mathrm{CO}_{2}, \mathrm{SO}_{2}$ released for each test conducted by means of gas density at CNTP.

The Elementary Analysis of the wood was obtained from specialized literature, dry basis, for the same species in the study, consisting of $48.33 \%$ carbon $(\mathrm{C}), 5.89 \%$ hydrogen $(\mathrm{H})$, $45.13 \%$ oxygen $(\mathrm{O}), 0.15 \%$ nitrogen $(\mathrm{N}) \quad 0.01 \%$ sulfur $(\mathrm{S})$ and $0.52 \%$ ash (A) [12].

Assuming that all carbon in the wood during the combustion reacts only producing $\mathrm{CO}$ and $\mathrm{CO}_{2}$, and that sulfur is completely converted into $\mathrm{SO}_{2}, \mathrm{H}_{2} \mathrm{O}$ and hydrogen in nitrogen in $\mathrm{N}_{2}$, the overall equation of the combustion 100 $\mathrm{kg}$ of wood in air $\left(\mathrm{O} 2+3.76 \mathrm{~N}_{2}\right)$, on the bas is of work, with a mo isture content of $11.8 \%$ and the conversion factor for dry basis based work of 0.8820 , is given by:

$$
\begin{aligned}
3,5491 \mathrm{C} & +5,1950 \mathrm{H}+2,4878 \mathrm{O}+0,0094 \mathrm{~N}+0,0003 \mathrm{~S} \\
& +0,6555 \mathrm{H}_{2} \mathrm{O}+0,4586+3,4268\left(\mathrm{O}_{2}+3,76 \mathrm{~N}_{2}\right) \\
& \rightarrow 3,1942 \mathrm{CO}_{2}+0,3549 \mathrm{CO}+0,0003 \mathrm{SO}_{2} \\
& +3,2530 \mathrm{H}_{2} \mathrm{O}+12,8895 \mathrm{~N}_{2}+0,4586
\end{aligned}
$$

In the statistical analysis, the influence of the type of stove $(1,2,3)$ in response variables of interest were evaluated using analysis of variance (ANOVA), Kruskal-Wallis test (nonparametric) and multiple comparisons between gas Student-Newman-Keuls test with the aid of BioEstat ${ }^{\circledR}$ version 5.0. The significance level $(\alpha)$ set for the ANOVA was $5 \%$, and the null hypothes is $\left(\mathrm{H}_{0}\right)$ formu lated consisted of equivalence between medium, imply ing the non-equivalence between means for the alternative hypothes is $\left(\mathrm{H}_{1}\right)$. $\mathrm{P}$-value of the Kruskal-Wallis higher than the level of significance

\begin{tabular}{|c|c|c|}
\hline \multicolumn{3}{|c|}{ Stove 1} \\
\hline & $\bar{x}$ & $c v(\%)$ \\
\hline Efficiency & $2.916 \pm 0.254$ & 9 \\
\hline Potency $(W)$ & $159.33 \pm 14.18$ & 9 \\
\hline Vol. of $\mathrm{CO}_{2}\left(\mathrm{Nm}^{3} / \mathrm{kg}\right)$ & $314.38 \pm 28.29$ & 9 \\
\hline Vol. of $\mathrm{SO}_{2}\left(\mathrm{Nm}^{3} / \mathrm{kg}\right)$ & $0.027 \pm 0.002$ & 9 \\
\hline Vol. of $\mathrm{CO}\left(\mathrm{Nm}^{3} / \mathrm{kg}\right)$ & $34.93 \pm 3.14$ & 9 \\
\hline \multicolumn{3}{|c|}{ Stove 2} \\
\hline & $\bar{x}$ & $c v(\%)$ \\
\hline Efficiency & $2.58 \pm 0.47$ & 18 \\
\hline Potency $(W)$ & $142.73 \pm 39.17$ & 27 \\
\hline Vol. of $\mathrm{CO}_{2}\left(\mathrm{Nm}^{3} / \mathrm{kg}\right)$ & $316.52 \pm 77$ & 24 \\
\hline Vol. of $\mathrm{SO}_{2}\left(\mathrm{Nm}^{3} / \mathrm{kg}\right)$ & $0.027 \pm 0.007$ & 24 \\
\hline Vol. of $\mathrm{CO}\left(\mathrm{Nm}^{3} / \mathrm{kg}\right)$ & $35.17 \pm 8.56$ & 24 \\
\hline \multicolumn{3}{|c|}{ Stove 3} \\
\hline & $\bar{x}$ & $c v(\%)$ \\
\hline Efficiency & $4.57 \pm 0.24$ & 5 \\
\hline Potency $(W)$ & $176.53 \pm 21.71$ & 12 \\
\hline Vol. of $\mathrm{CO}_{2}\left(\mathrm{Nm}^{3} / \mathrm{kg}\right)$ & $220.91 \pm 19$ & 8 \\
\hline Vol. of $\mathrm{SO}_{2}\left(\mathrm{Nm}^{3} / \mathrm{kg}\right)$ & $0.019 \pm 0.002$ & 8 \\
\hline Vol. of $\mathrm{CO}\left(\mathrm{Nm}^{3} / \mathrm{kg}\right)$ & $24.55 \pm 2.06$ & 8 \\
\hline
\end{tabular}
involves accepting $\mathrm{H}_{0}$, rejecting it otherwise.

\section{Results}

Table 3 presents the results of the physical and chemical properties of the investigated ranges evaluated, $\bar{x}$ e $c v$ med iu m sample and coefficient of variation, respectively.

Table 3. Results of the physical and chemical properties investigated

Figure 4 illustrates the results investigated and the properties shown in Table 3 for the three types of oven evaluated. 


\section{Efficiency}

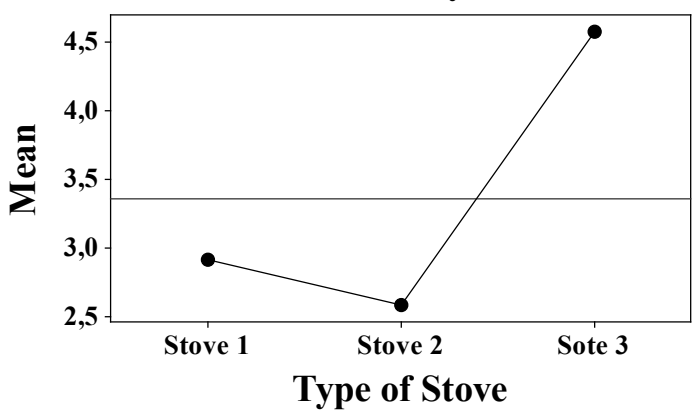

(a)

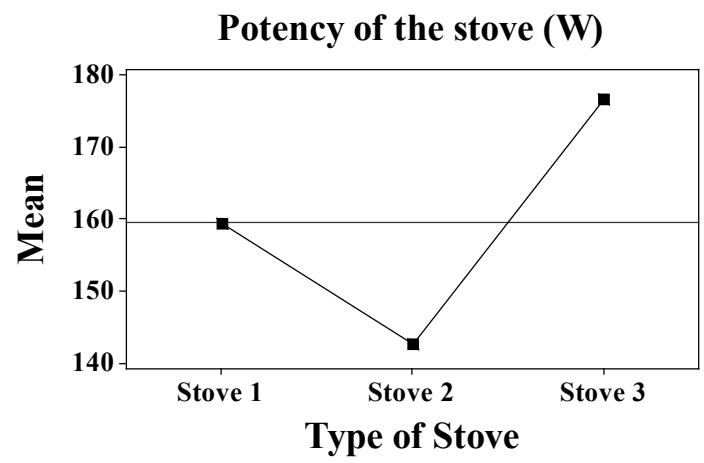

(b)

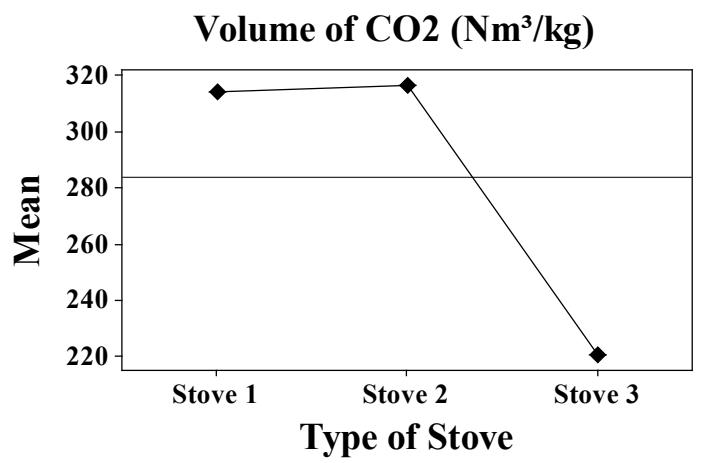

(c)

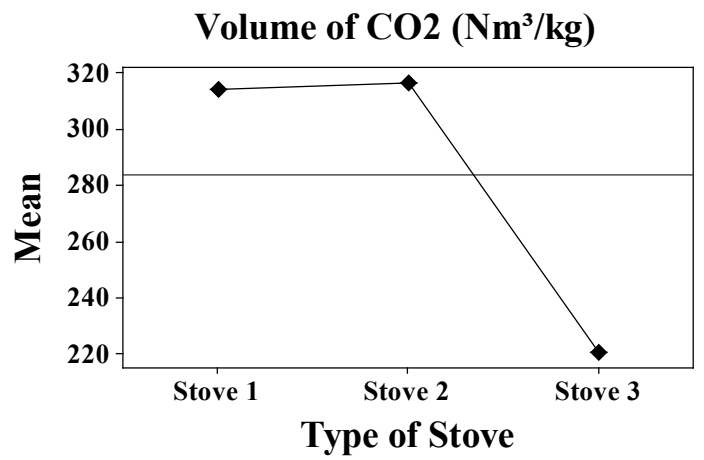

(d)

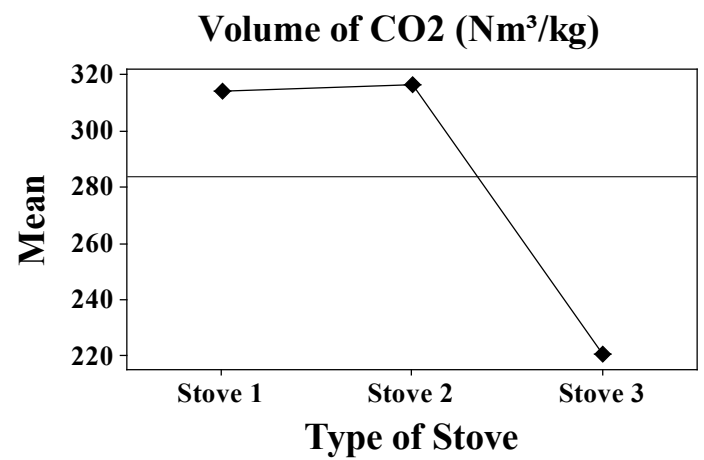

(e)

Figure 4. Variation of the properties investigated by stove type

Table 4 shows the results of analys is of variance according to the Kruskal-Wallis test and multiple comparisons between stations Student-Newman-Keuls test for the response variables investigated, being underlined P-values below 0.05 were considered significant to a confidence level of $95 \%$. The value 1, 2 and 3 of the groups shown in table 2 refers to the three types of ovens evaluated, respectively.

Table 4. ANOVAresults and comparisons by Student-Newman-Keuls

\begin{tabular}{|c|c|c|c|c|c|c|}
\hline Response & $\mathbf{H}$ & DF & \multicolumn{2}{|c|}{ P-value } & R1 & $\mathbf{R 2}$ \\
\hline Efficiency & 10.2 & 2 & \multicolumn{2}{|c|}{$\underline{0.0060}$} & 6.80 & 4.20 \\
\hline Potency $(W)$ & 3.35 & 2 & \multicolumn{2}{|c|}{0.1872} & - & - \\
\hline $\begin{array}{l}\text { Vol. of } \mathrm{CO}_{2} \\
\left(\mathrm{Nm}^{3} / \mathrm{kg}\right)\end{array}$ & 6.62 & 2 & \multicolumn{2}{|c|}{$\underline{0.0365}$} & 10.20 & 10.00 \\
\hline $\begin{array}{l}\text { Vol. of } \mathrm{SO}_{2} \\
\left(\mathrm{Nm}^{3} / \mathrm{kg}\right)\end{array}$ & 6.62 & 2 & \multicolumn{2}{|c|}{$\underline{0.0365}$} & 10.20 & 10.00 \\
\hline $\begin{array}{l}\text { Vol. of CO } \\
\left(\mathrm{Nm}^{3} / \mathrm{kg}\right)\end{array}$ & 6.62 & 2 & \multicolumn{2}{|c|}{$\underline{0.0365}$} & 10.20 & 10.00 \\
\hline Response & $\mathbf{R 3}$ & \multicolumn{2}{|c|}{$\begin{array}{c}\text { Groups } \\
(1 \text { e } 2)\end{array}$} & \multicolumn{2}{|c|}{$\begin{array}{c}\text { Groups } \\
(1 \text { e } 3)\end{array}$} & $\begin{array}{c}\text { Groups } \\
(2 \text { e } 3) \\
\end{array}$ \\
\hline Efficiency & 13.00 & \multicolumn{2}{|c|}{0.36} & \multicolumn{2}{|c|}{0.028} & 0.0019 \\
\hline Potency $(W)$ & - & \multicolumn{2}{|c|}{-} & \multicolumn{2}{|c|}{-} & - \\
\hline $\begin{array}{l}\text { Vol. of } \mathrm{CO}_{2} \\
\left(\mathrm{Nm}^{3} / \mathrm{kg}\right)\end{array}$ & 3.80 & \multicolumn{2}{|c|}{0.94} & \multicolumn{2}{|c|}{0.024} & 0.0284 \\
\hline $\begin{array}{c}\text { Vol. of } \mathrm{SO}_{2} \\
\left(\mathrm{Nm}^{3} / \mathrm{kg}\right)\end{array}$ & 3.80 & \multicolumn{2}{|c|}{0.94} & \multicolumn{2}{|c|}{0.024} & 0.0284 \\
\hline $\begin{array}{l}\text { Vol. of CO } \\
\left(\mathrm{Nm}^{3} / \mathrm{kg}\right)\end{array}$ & 3.80 & \multicolumn{2}{|c|}{0.94} & \multicolumn{2}{|c|}{0.024} & 00284 \\
\hline
\end{tabular}

Table 5 shows the results of groups based on data in Table 4. Different letters determine medium statistically different at the $95 \%$ level of probability.

Table 5. Grouping fact or type of stove for response variable

\begin{tabular}{cccc}
\hline Response & Stove 1 & Stove 2 & Stove 3 \\
\hline Efficiency & B & B & A \\
Potency $(W)$ & A & A & A \\
Vol. of $\mathrm{CO}_{2}\left(\mathrm{Nm}^{3} / \mathrm{kg}\right)$ & A & A & B \\
Vol. of $\mathrm{SO}_{2}\left(\mathrm{Nm}^{3} / \mathrm{kg}\right)$ & A & A & B \\
Vol. of $\mathrm{CO}\left(\mathrm{Nm}^{3} / \mathrm{kg}\right)$ & A & A & B \\
\hline
\end{tabular}

The results obtained from Table 5 reveille that the Stove 3 
presented to be the most efficient in terms of power that no significant differences between the ranges evaluated, and with respect to emissions, the stove 3 showed the lowest values, enabling complete, in general, that the stove was the third best of the stoves evaluated.

\section{Conclusions}

The results show that the stoves had low energy efficiency, and the stove 3, by having a system of thermal insulation of the combustion chamber, the model more efficient, powerful and that result in lower polluted emissions. The stove 2 showed the worst results. This is justified due to its lower efficiency in the use of fuel as well as the loss of heat to the metal walls. One improvement that could be applied to ranges 1 and 2 would be the introduction of thermal insulation in the combustion chamber, thereby avoiding excessive heat loss in the metal walls of high thermal conductivity. All stoves have high levels of volatile release, with the presence of toxic gases such as carbon monoxide. Thus, there is great interest in research aimed at evaluating the efficiency of thermal power and fuel wood traditionally used in Brazil, as well as proposals for new designs that have higher efficiency and lower emissions.

\section{REFERENCES}

[1] Brito, J. O.; Cintra, T.C. Madeira para energia no Brasil: realidade, visão estratégica e demanda de ações. Biomassa \& Energia, v. 1, n. 2, p. 157-163, 2004.

[2] Schallenberger, L. S.; Araujo, A. J.; Araujo, M. N.; Deiner, L. J.; Machado, G. O. Avaliação da Condição de Árvores Urbanas nos principais Parques e Praças do Município de Irati-PR. Revista da Sociedade Brasileira de Arborização Urbana, v. 5, p. 105-123, 2010.
[3] Northcross, A. L.; Hammond, S. K.; Canuz, E.; Smith, K. R. Dioxin inhalation doses from wood combustion in indoor cookfires. Atmospheric Environment, v. 49, p. 415-418, 2012.

[4] Nogueira, L. A. H.; Lora, E. E. S. Dendroenergia: fundamentos e aplicações. Rio de Janeiro: Editora Interciência, 2003.

[5] Regueira, T. M. Comparação entre a eficiência de dois modelos de fogão a lenha e seus impactos sobre o desmatamento da caatinga. Trabalho de conclusão de curso de Bacharelado em Ciências Biológicas. Universidade Federal de Pernambuco, Pernambuco, 2010.

[6] Brito, J. O. O uso energético da madeira. Estudos Avançados, v. 21, n. 59, p.185-193, 2007.

[7] Borges, T.P.F. Fogão a lenha de combustão limpa. Universidade Estadual de Campinas, 1994.

[8] Brito, J. O. Expressão da produção florestal em unidades energéticas. In Congresso Florestal Panamericano, 1, 1993, Curitiba; Congresso Florestal Brasileiro, 7, 1993, Curitiba. Anais... Curitiba: Sociedade Brasileira de Silvicultura, 199, p. 280-282.

[9] American Society for Testing and Material ASTM E711-87. Standard test method for gross calorific value of refuse-derived fuel by the bomb calorimeter. West Conshohocken, PA, USA, 2004.

[10] Parikh, J.; Channiwala, S. A.; Ghosal G.K. A correlation for calculating HHV from proximate analy sis of solid fuels. Fuel. Vol. 84, p. 487-494, 2005.

[11] Jossi, V.; Venkataraman, C.; Ahuja, D. R. Emissions from Burning Biofuels in Metal Cookstoves. Environmental Management, Vol. 13, N. 6, pp 763-772, 1989.

[12] Demirbas, A., Ilten, N. Fuel analyses and thermochemical processing of olive residues. Energy Sources, 26:731-738, 2004. 